\title{
Prevalence and risk factors of atrioventricular block among 15 million Chinese health examination participants in 2018: a nation-wide cross-sectional study
}

\author{
Ruiqi Shan ${ }^{1}$, Yi Ning ${ }^{2,4^{*}}$, Yuan Ma ${ }^{4}$, Siliang Liư ${ }^{5}$, Jing Wu${ }^{1}$, Xiaohan Fan ${ }^{6}$, Jun Lv ${ }^{1,2,3}$, Bo Wang ${ }^{2,4}$, Shijun Li $i^{4}$ and \\ Liming $\mathrm{Li}^{1,2,3^{*}}$
}

\begin{abstract}
Background: Nationwide data on the prevalence of atrioventricular (AV) block are currently unavailable in China. Thus, we aimed to assess the prevalence and risk factors of AV block among Chinese health examination adults.

Methods: A total of 15,181,402 participants aged $\geq 18$ years (mean age $41.5 \pm 13.4$ years, $53.2 \%$ men) who underwent an electrocardiogram as a part of routine health examination in 2018 were analyzed. AV block was diagnosed by physicians using 12-lead electrocardiogram. Overall and stratified prevalence (by age, sex, and city size) of all, first-, second- and third-degree AV block were calculated. Multivariable logistic regression analyses were performed to explore risk factors associated with AV block.

Results: AV block was observed in 88,842 participants, including 86,153 with first-degree, 2249 with second-degree and 440 with third-degree AV block. The age- and sex-standardized prevalence rate [95\% confidence interval (CI)] of all, first-, second- and third-degree AV block were 7.06\%o (7.01-7.11), 6.84\%o (6.79-6.89), 0.18\%o (0.17-0.18) and 0.04\%o (0.03-0.04) respectively. After multivariable adjustment, the risk of AV block was positively associated with older age, being male, lower heart rate, higher body mass index, hypertension, diabetes and low high-density lipoprotein cholesterol. High total cholesterol was associated with a lower risk of AV block.

Conclusion: First-degree AV block is relatively common while severe AV block is rare in health examination adults. Besides, AV block was highly prevalent among the elderly. The risk of AV block was associated with older age, being male and metabolic factors.
\end{abstract}

Keywords: Atrioventricular block, Epidemiology, Prevalence, China, Risk factor

*Correspondence: Yi.Ning@MeinianResearch.com; Imlee@vip.163.com ${ }^{1}$ Department of Epidemiology and Biostatistics, School of Public Health, Peking University Health Science Center, 38 Xueyuan Road Beijing 100191, China

2 Peking University Health Science Center Meinian Public Health Institute,

35 North Huayuan Road, Beijing 100191, China

Full list of author information is available at the end of the article

\section{Introduction}

Atrioventricular (AV) block is a loss of normal function of the cardiac conductive pathway between the atrium and the ventricle. It can be divided into three degrees: firstdegree, second-degree (type-I or II) and third-degree [1, 2]. The first-degree and type-I second-degree AV block are considered to be relatively benign conditions $[1,2]$. However, accumulating evidence suggests that PR interval prolongation, which is the electrocardiograph feature 
of the first-degree and type-I second-degree AV block, is associated with atrial fibrillation [3], heart failure [4] and mortality [3-5]. Moreover, the prognosis of type-II second-degree and third-degree AV block are generally poor and always require clinical treatment such as medication or pacemaker implantation [6,7]. Without proper and timely treatment, AV block might lead to death [3-6].

Given the potential serious threats to human health, it is necessary to investigate the early development of AV block. However, to our knowledge, such studies are scarce in China and worldwide, especially among ostensibly healthy population. Only one study investigated the prevalence of first-degree AV block among 10,926 participants in China. Nevertheless, the study conduct among residents aged $\geq 40$ years in rural Northeast China [8]. Moreover, no Chinese data on the prevalence of second and third-degree AV block are available among ostensibly healthy population.

In this study, we aimed to examine the prevalence of first-, second- and third-degree AV block and explored related risk factors of AV block based on the database of $15,181,402$ Chinese adults from 30 provinces who underwent a 12-lead electrocardiogram (ECG) as a part of routine health examination in 2018.

\section{Methods}

\section{Study design and participants}

This study was conducted using the database of Meinian Healthcare Group, which is the top non-public health examination institution and provides health examination across China. Each health screening centers equipped with professional and experienced medical teams provided comprehensive health examinations for participants.

In the current analysis, we extracted data between January 1st, 2018 and December 31st, 2018, which were derived from 454 centers from 224 cities in 30 provinces. Among 16,988,851 adults aged 18 years or older, after excluding missing value in sex $(\mathrm{n}=15)$ and ECG $(\mathrm{n}=1,807,434), 15,181,402$ adults (89\% of the participants) with routine ECG test were included in the final analysis.

The study was approved by the Peking University Institutional Review Board with a waiver of informed consent (IRB00001052-19077). Data on individual identification were removed and only anonymous information was kept during the study process.

\section{Assessment of AV block}

A twelve-lead standard ECG was performed for each participant. First-degree AV block was defined as abnormal prolongation of the PR interval (greater than $0.2 \mathrm{~s}$ ) and each atrial excitement is transmitted to the ventricle.
Second-degree AV block was defined as atrial impulse partly cannot be transmitted to the ventricular. Thirddegree AV block was defined as complete absence of atrioventricular conduction [2]. All ECGs were reading by at least two well-trained cardiologist. In case of controversy, a senior cardiologist was consulted for a final diagnosis or until agreement was reached with discussion.

\section{Assessment of social demography, anthropometric and laboratory factors}

The demographic and clinical history were obtained by health professional through face to face interview. City size was determined according to urban population size. For better understand we reclassified urban population size as follow: more than five million as big city, one to five million as middle city, less than one million as small city [9].

Anthropometric data such as height, weight, blood pressure and heart rate were measured using standard methods. Hypertension was defined as systolic blood pressure $\geq 140 \mathrm{mmHg}$ and/or diastolic blood pressure $\geq 90 \mathrm{mmHg}$ and/or self-reported history of hypertension and/or use of antihypertensive treatment [10]. Body mass index (BMI) was calculated as weight $(\mathrm{kg}) /$ height $(\mathrm{m})^{2}$ and was categorized into $<18.5 \mathrm{~kg} / \mathrm{m}^{2}$ (underweight), $18.5 \mathrm{~kg} / \mathrm{m}^{2} \leq \mathrm{BMI}<24 \mathrm{~kg} / \mathrm{m}^{2}$ (normal), $24 \mathrm{~kg} / \mathrm{m}^{2} \leq \mathrm{BMI}<28 \mathrm{~kg} / \mathrm{m}^{2}$ (overweight), and $\geq 28 \mathrm{~kg} / \mathrm{m}^{2}$ (obese), respectively [11].

Blood samples were drawn by venipuncture after 8-12 h of overnight fasting to measure fasting blood glucose (FBG), high-density lipoprotein cholesterol (HDL-C), low-density lipoprotein cholesterol (LDL-C), total cholesterol (TC) and triglyceride (TG). Laboratory measurements were measured with commercially available reagents at the clinical biochemical laboratories in each center. Diabetes was defined as FBG $\geq 7.0 \mathrm{mmol} / \mathrm{L}$ and/or self-reported history of diabetes [12]. Low HDL-C was defined HDL-C $<1.0 \mathrm{mmol} / \mathrm{L}$. High LDL-C was defined as LDL-C $\geq 4.1 \mathrm{mmol} / \mathrm{L}$. High TC was defined as $\mathrm{TC} \geq 6.2 \mathrm{mmol} / \mathrm{L}$. High TG was defined as $\mathrm{TG} \geq 2.3 \mathrm{mmol} / \mathrm{L}$ [13].

\section{Statistical analysis}

Characteristics of the participants are presented as No. (\%) for categorical variables. Chi square tests were used to compare differences in categorical variables between participants with and without AV block. Age- and sexstandardized prevalence with $95 \%$ confidence interval (CI) was calculated according to population of 2010 China Population Sampling Census using direct standardization method. Age-standardized prevalence was calculated for men and women, respectively. Sex-standardized prevalence was calculated for specific age group. 
Chi square tests was applied to compare rates in different subgroups. Unadjusted, age and sex adjusted, and multivariable logistic regression analyses (adjusting for age, sex, city size, heart rate, BMI, hypertension, diabetes, low HDL-C, high LDL-C, high TC and high TG) were conducted to investigate risk factors for AV block. Curve graph of prevalence rates by different age was drawn using GraphPad Prism 8. Map of prevalence rates across 30 provinces was drawn using $\mathrm{R}$ version 4.0.4 (http:// www.r-project.org/) to present geographical variation visually. Analyses were conducted using SAS, version 9.3 (SAS Institute, Inc., Cary, North Carolina). $P<0.05$ was considered statistically significant.

\section{Results}

Among the 15,181,402 study participants, 88,842 participants were diagnosed with AV block, including 86,153 with first-degree, 2249 with second-degree and 440 with third-degree AV block. Characteristics of the participants by AV block status are presented in Table 1. Compared with those without AV block, participants with AV block were more likely to be older, men, with lower heart rate, with higher BMI and living in cities with smaller urban population size, and have a higher proportion of hypertension, diabetes, low HDL-C, high LDL-C, high TC and high TG (Table 1).

Age- and sex-standardized prevalence $(95 \% \mathrm{CI})$ for all, first-, second- and third-degree AV block were $7.06 \%$ (7.01-7.11), 6.84\%o (6.79-6.89), 0.18\%o (0.17-0.18) and $0.04 \%$ (0.03-0.04), respectively. The prevalence was higher among older participants (age $\geq 60$ years vs. age $18-39$ years: $18.0 \%$ vs. $2.67 \%$ for all AV block; $17.5 \%$ vs. $2.55 \%$ for first-degree AV block; $0.42 \%$ vs. $0.10 \%$ o for second-degree AV block; $0.10 \%$ vs. $0.02 \%$ for thirddegree AV block), higher among men (men vs. women: $10.3 \%$ vs. $3.92 \%$ for all AV block; $9.98 \%$ vs. $3.78 \%$ for first-degree AV block; $0.25 \%$ vs. $0.12 \%$ for seconddegree AV block; $0.05 \%$ vs. $0.03 \%$ for third-degree AV block), higher among small city (small city vs. big city: 8.02\%o vs. $5.38 \%$ for all AV block; $7.76 \%$ vs. $5.18 \%$ o for first-degree AV block; $0.21 \%$ vs. $0.17 \%$ for seconddegree AV block; $0.05 \%$ vs. $0.03 \%$ for third-degree AV block) (Table 2).

In multivariable-adjusted models, older age (per 10 years increment OR 1.66, 95\% CI 1.64-1.67), being male (OR 2.44, 95\% CI 2.39-2.49), higher BMI (per $5 \mathrm{~kg} /$ $\mathrm{m}^{2}$ increment OR $1.26,95 \%$ CI 1.24-1.28), hypertension (OR 1.08, 95\% CI 1.06-1.11), diabetes (OR 1.20, 95\% CI $1.17-1.23)$ and low HDL-C (OR 1.19, 95\% CI 1.15-1.22) were associated with an increased risk of AV block. Living in big city (OR 0.78, 95\% CI 0.76-0.80), higher heart rate (per $10 \mathrm{bpm}$ increment OR 0.69, 95\% CI 0.68-0.70) and high TC (OR $0.88,95 \%$ CI $0.85-0.91)$ were associated with a decreased risk of AV block after multivariable adjustment. $P<0.001$ for all (Table 3 ).

As shown in Fig. 1 and Additional file 1: Table S1, the prevalence of $\mathrm{AV}$ block was lowest in age 18-22 years (men: $0.23 \%$; women: $0.13 \%$ ) then gradually increased. Notably, the prevalence dramatically increased from age 53-57 years (men: 1.15\%; women: $0.48 \%$ ) and then reached the peak in age $\geq 78$ years (men: $7.49 \%$; women: 2.97\%).

As shown in Fig. 2 and Additional file 1: Table S2, the provinces with age- and sex-standardized prevalence of AV block higher than $10 \%$ were Xinjiang (11.1\%), Hainan (10.8\%o), Ningxia (10.8\%) and Qinghai (10.7\%o), respectively. The provinces with age- and sex-standardized prevalence of AV block lower than 4\%o were Shanghai $(2.8 \%)$, Jilin $(3.1 \%)$ and Tianjin $(3.6 \%)$, respectively.

\section{Discussion}

In this study, we reported on the prevalence of all, first-, second- and third-degree AV block among 15 million Chinese adults aged $\geq 18$ years who underwent routine physical examination during 2018. The age- and sexstandardized prevalence rates of all, first-, second- and third-degree AV block were $7.06 \%$, 6.84\%, $0.18 \%$ and $0.04 \%$, respectively. Further, older age, being male, lower heart rate, higher BMI, hypertension, diabetes and low HDL-C were associated with a higher risk of AV block. Living in big city and high TC were associated with a lower risk of AV block after multivariable adjustment.

To the best of our knowledge, this is the first nationwide study investigating the prevalence of first-, second- and third-degree AV block simultaneously. There is only one study investigated the prevalence of firstdegree AV block in China prior to our study. However, this study only focus on the residents aged $\geq 40$ years in rural Northeast China [8]. Our study is the first study investigated the prevalence of first-degree AV block among adults aged $\geq 18$ years across mainland China (except Tibet). The prevalence of first-degree AV block was reported to be $2 \%$ among Finnish general population aged $30-59$ years (mean age, 44 years) [5] and 1.6\% among Framingham general population aged $\geq 20$ years (mean age, 47 years) [3]. Besides, in Asia, it reported to be $1.9 \%$ among Japanese general population aged $30-95$ years (mean age, 49.9 years) (PR interval greater than $0.22 \mathrm{~s}$ ) [14] and 3.4\% among residents aged $\geq 40$ years (mean age, 59.8 years) in rural Northeast China [8]. In our study, the prevalence of first-degree AV block was $0.68 \%$ which is relatively lower than those above-mentioned studies. This discrepancy may be partly due to the study participants are younger (aged $\geq 18$ years, mean age, 41.5 years) and the majority of participants are ostensibly healthy in 
Table 1 Characteristics of study participants by atrioventricular block status

\begin{tabular}{|c|c|c|c|c|c|c|}
\hline & \multirow[t]{2}{*}{ Overall } & \multirow[t]{2}{*}{ Without AV block } & \multicolumn{4}{|c|}{ Participants with AV block } \\
\hline & & & All & First degree & Second degree & Third degree \\
\hline N & $15,181,402$ & $15,092,560$ & 88,842 & 86,153 & 2249 & 440 \\
\hline \multicolumn{7}{|l|}{ Age, years } \\
\hline 18-39 & $7,609,253(50.1)$ & $7,588,277(50.3)$ & $20,976(23.6)$ & $20,072(23.3)$ & $784(34.9)$ & $120(27.3)$ \\
\hline $40-59$ & $5,896,375(38.8)$ & $5,859,173(38.8)$ & $37,202(41.9)$ & $36,302(42.1)$ & $750(33.3)$ & $150(34.1)$ \\
\hline$\geq 60$ & $1,675,774(11.0)$ & $1,645,110(10.9)$ & $30,664(34.5)$ & $29,779(34.6)$ & $715(31.8)$ & $170(38.6)$ \\
\hline \multicolumn{7}{|l|}{ Sex } \\
\hline Men & $8,079,772(53.2)$ & $8,013,421(53.1)$ & $66,351(74.7)$ & $64,499(74.9)$ & $1567(69.7)$ & $285(64.8)$ \\
\hline Women & $7,101,630(46.8)$ & $7,079,139(46.9)$ & $22,491(25.3)$ & $21,654(25.1)$ & $682(30.3)$ & $155(35.2)$ \\
\hline \multicolumn{7}{|l|}{ City size ${ }^{*}$} \\
\hline Small city & $4,570,409(30.1)$ & $4,536,248(30.1)$ & $34,161(38.5)$ & $33,106(38.4)$ & $873(38.8)$ & $182(41.4)$ \\
\hline Middle city & $6,094,497(40.1)$ & $6,058,120(40.1)$ & $36,377(40.9)$ & $35,452(41.2)$ & $773(34.4)$ & $152(34.5)$ \\
\hline Big city & $4,516,496(29.8)$ & $4,498,192(29.8)$ & 18,304 (20.6) & $17,595(20.4)$ & $603(26.8)$ & $106(24.1)$ \\
\hline \multicolumn{7}{|c|}{ Heart rate, bpm } \\
\hline$<60$ & $377,629(3.4)$ & $372,179(3.4)$ & $5450(8.3)$ & $4931(7.7)$ & $360(21.7)$ & $159(50.2)$ \\
\hline $60-100$ & $10,614,677(95.6)$ & $10,554,664$ (95.6) & $60,013(91.2)$ & $58,570(91.8)$ & $1285(77.6)$ & $158(49.8)$ \\
\hline$>100$ & $115,780(1.0)$ & $115,443(1.0)$ & $337(0.5)$ & $326(0.5)$ & $11(0.7)$ & 0 \\
\hline \multicolumn{7}{|l|}{$\mathrm{BMI}, \mathrm{kg} / \mathrm{m}^{2}$} \\
\hline$<18.5$ & $640,013(4.7)$ & $638,248(4.7)$ & $1765(2.2)$ & $1646(2.1)$ & $92(4.6)$ & $27(6.8)$ \\
\hline $18.5-23.9$ & $6,504,666(47.6)$ & $6,476,822(47.7)$ & $27,844(34.6)$ & $26,731(34.2)$ & $945(46.9)$ & $168(42.3)$ \\
\hline $24-27.9$ & $4,690,273(34.3)$ & $4,655,934(34.3)$ & $34,339(42.6)$ & $33,456(42.8)$ & $730(36.2)$ & $153(38.5)$ \\
\hline$\geq 28.0$ & $1,825,423(13.4)$ & $1,808,789(13.3)$ & $16,634(20.6)$ & $16,337(20.9)$ & $248(12.3)$ & $49(12.3)$ \\
\hline \multicolumn{7}{|l|}{ Hypertension } \\
\hline No & $11,469,363(78.1)$ & $11,417,566(78.2)$ & $51,797(60.3)$ & $50,128(60.2)$ & $1442(66.3)$ & $227(53.5)$ \\
\hline Yes & $3,209,2182(21.9)$ & $3,175,183(21.8)$ & $34,099(39.7)$ & $33,168(39.8)$ & $734(33.7)$ & $197(46.5)$ \\
\hline \multicolumn{7}{|l|}{ Diabetes } \\
\hline No & $13,851,682(94.9)$ & $13,775,997(95.0)$ & 75,685 (87.9) & $73,307(87.8)$ & 1990 (91.5) & $388(90.2)$ \\
\hline Yes & $749,368(5.1)$ & $738,904(5.1)$ & $10,464(12.1)$ & $10,237(12.3)$ & $185(8.5)$ & $42(9.8)$ \\
\hline \multicolumn{7}{|l|}{ Low HDL-C } \\
\hline No & $9,477,347(91.1)$ & $9,415,791(91.1)$ & $61,556(87.7)$ & $59,759(87.6)$ & $1504(90)$ & $293(92.7)$ \\
\hline Yes & $925,535(8.9)$ & $916,866(8.9)$ & $8669(12.3)$ & 8479 (12.4) & $167(10)$ & $23(7.3)$ \\
\hline \multicolumn{7}{|l|}{ High LDL-C } \\
\hline No & $9,700,780(93.7)$ & $9,635,735(93.7)$ & $65,045(92.9)$ & $63,187(92.9)$ & 1567 (93.9) & $291(92.4)$ \\
\hline Yes & $651,784(6.3)$ & $646,837(6.3)$ & $4947(7.1)$ & $4822(7.1)$ & $101(6.1)$ & $24(7.6)$ \\
\hline \multicolumn{7}{|l|}{ High TC } \\
\hline No & $12,305,558(91.2)$ & $12,229,928(91.2)$ & $75,630(90.3)$ & $73,356(90.2)$ & 1901 (92.2) & $373(91.4)$ \\
\hline Yes & $1,186,254(8.8)$ & $1,178,085(8.8)$ & $8169(9.7)$ & $7974(9.8)$ & $160(7.8)$ & $35(8.6)$ \\
\hline \multicolumn{7}{|l|}{ High TG } \\
\hline No & $11,386,284(84.5)$ & $11,318,687(84.6)$ & $67,597(80.8)$ & $65,443(80.6)$ & 1799 (87.6) & $355(87.4)$ \\
\hline Yes & $2,082,218(15.5)$ & $2,066,129(15.4)$ & 16,089 (19.2) & $15,784(19.4)$ & $254(12.4)$ & $51(12.6)$ \\
\hline
\end{tabular}

Characteristics of the participants are presented as No. (\%) for categorical variables. $P<0.001$ for all comparisons between participants with and without AV block $A V$ atrioventricular, BMI body mass index, Low HDL-C high-density lipoprotein cholesterol $<1.0 \mathrm{mmol} / \mathrm{L}$, High LDL-C low-density lipoprotein cholesterol $\geq 4.1 \mathrm{mmol} / \mathrm{L}$, High TC total cholesterol $\geq 6.2 \mathrm{mmol} / \mathrm{L}$, High TG triglyceride $\geq 2.3 \mathrm{mmol} / \mathrm{L}$

${ }^{*}$ City size was determined according to urban population size

the present study. While, the prevalence was relatively close to that reported among United States male flying personnel aged $\geq 16$ years $(0.65 \%)$ [15] and among Swiss conscripts aged $17-38$ years $(0.76 \%)$ [16]. To the best of our knowledge, no epidemiology studies have been conducted on the prevalence of second-degree AV block in China and it was reported to be $0.018 \%$ in our study. The prevalence of second-degree AV block was 
Table 2 The prevalence of atrioventricular block among Chinese health examination adults in 2018

\begin{tabular}{|c|c|c|c|c|c|c|c|c|}
\hline & \multicolumn{2}{|c|}{$\begin{array}{l}\text { All AV block (no. of } \\
\text { cases }=88,842 \text { ) }\end{array}$} & \multicolumn{2}{|c|}{$\begin{array}{l}\text { First degree AV block (no. of } \\
\text { cases }=86,153 \text { ) }\end{array}$} & \multicolumn{2}{|c|}{$\begin{array}{l}\text { Second degree AV block (no. } \\
\text { of cases = 2249) }\end{array}$} & \multicolumn{2}{|c|}{$\begin{array}{l}\text { Third degree AV block (no. of } \\
\text { cases }=440 \text { ) }\end{array}$} \\
\hline & $\begin{array}{l}\text { Crude } \\
\text { prevalence }\end{array}$ & $\begin{array}{l}\text { Standardized } \\
\text { prevalence }^{\mathrm{a}}\end{array}$ & $\begin{array}{l}\text { Crude } \\
\text { prevalence }\end{array}$ & $\begin{array}{l}\text { Standardized } \\
\text { prevalence }^{\mathrm{a}}\end{array}$ & $\begin{array}{l}\text { Crude } \\
\text { prevalence }\end{array}$ & $\begin{array}{l}\text { Standardized } \\
\text { prevalence }^{\mathrm{a}}\end{array}$ & $\begin{array}{l}\text { Crude } \\
\text { prevalence }\end{array}$ & $\begin{array}{l}\text { Standardized } \\
\text { prevalence }^{\mathrm{a}}\end{array}$ \\
\hline Total & $\begin{array}{l}5.85(5.81- \\
5.89)\end{array}$ & $7.06(7.01-7.11)$ & $\begin{array}{l}5.67(5.64- \\
5.71)\end{array}$ & $6.84(6.79-6.89)$ & $\begin{array}{l}0.15(0.14- \\
0.15)\end{array}$ & $0.18(0.17-0.18)$ & $\begin{array}{l}0.03(0.03- \\
0.03)\end{array}$ & $0.04(0.03-0.04)$ \\
\hline \multicolumn{9}{|l|}{ Age, years } \\
\hline $18-39$ & $\begin{array}{l}2.76(2.72- \\
2.79)\end{array}$ & $2.67(2.63-2.70)$ & $\begin{array}{l}2.64(2.60- \\
2.67)\end{array}$ & $2.55(2.51-2.59)$ & $\begin{array}{l}0.10(0.10- \\
0.11)\end{array}$ & $0.10(0.09-0.01)$ & $\begin{array}{l}0.02(0.01- \\
0.02)\end{array}$ & $0.02(0.01-0.02)$ \\
\hline $40-59$ & $\begin{array}{l}6.31(6.25- \\
6.37)\end{array}$ & $6.23(6.16-6.29)$ & $\begin{array}{l}6.16(6.09- \\
6.22)\end{array}$ & $6.08(6.01-6.14)$ & $\begin{array}{l}0.13(0.12- \\
0.14)\end{array}$ & $0.13(0.12-0.14)$ & $\begin{array}{l}0.03(0.02- \\
0.03)\end{array}$ & $0.03(0.02-0.03)$ \\
\hline$\geq 60$ & $\begin{array}{l}18.3(18.1- \\
18.5)\end{array}$ & $18.0(17.8-18.3)$ & $\begin{array}{l}17.8(17.6- \\
18.0)\end{array}$ & $17.5(17.3-17.7)$ & $\begin{array}{l}0.43(0.40- \\
0.46)\end{array}$ & $0.42(0.39-0.45)$ & $\begin{array}{l}0.10(0.09- \\
0.12)\end{array}$ & $0.10(0.09-0.12)$ \\
\hline \multicolumn{9}{|l|}{ Sex } \\
\hline Men & $\begin{array}{l}8.21(8.15- \\
8.27)\end{array}$ & $10.3(10.2-10.4)$ & $\begin{array}{l}7.98(7.92- \\
8.04)\end{array}$ & $9.98(9.89-10.1)$ & $\begin{array}{l}0.19(0.18- \\
0.20)\end{array}$ & $0.25(0.24-0.26)$ & $\begin{array}{l}0.04(0.03- \\
0.04)\end{array}$ & $0.05(0.04-0.06)$ \\
\hline Women & $\begin{array}{l}3.17(3.13- \\
3.21)\end{array}$ & $3.92(3.86-3.98)$ & $\begin{array}{l}3.05(3.01- \\
3.09)\end{array}$ & $3.78(3.72-3.83)$ & $\begin{array}{l}0.10(0.09- \\
0.10)\end{array}$ & $0.12(0.11-0.12)$ & $\begin{array}{l}0.02(0.02- \\
0.03)\end{array}$ & $0.03(0.02-0.03)$ \\
\hline \multicolumn{9}{|l|}{ City size* } \\
\hline Small city & $7.47(7.4-7.55)$ & $8.02(7.92-8.11)$ & $\begin{array}{l}7.24(7.17- \\
7.32)\end{array}$ & $7.76(7.67-7.85)$ & $\begin{array}{l}0.19(0.18- \\
0.20)\end{array}$ & $0.21(0.20-0.23)$ & $\begin{array}{l}0.04(0.03- \\
0.05)\end{array}$ & $0.05(0.04-0.06)$ \\
\hline Middle city & $\begin{array}{l}5.97(5.91- \\
6.03)\end{array}$ & $7.37(7.29-7.46)$ & $\begin{array}{l}5.82(5.76- \\
5.88)\end{array}$ & $7.17(7.09-7.26)$ & $\begin{array}{l}0.13(0.12- \\
0.14)\end{array}$ & $0.17(0.15-0.18)$ & $\begin{array}{l}0.03(0.02- \\
0.03)\end{array}$ & $0.04(0.03-0.04)$ \\
\hline Big city & $\begin{array}{l}4.05(3.99- \\
4.11)\end{array}$ & $5.38(5.29-5.47)$ & $\begin{array}{l}3.90(3.84- \\
3.95)\end{array}$ & $5.18(5.10-5.27)$ & $\begin{array}{l}0.13(0.12- \\
0.14)\end{array}$ & $0.17(0.16-0.19)$ & $\begin{array}{c}0.02(0.02- \\
0.03)\end{array}$ & $0.03(0.02-0.03)$ \\
\hline
\end{tabular}

Prevalence rates are presented as \%o (95\% confidence interval)

$A V$ atrioventricular

${ }^{*}$ City size was determined according to urban population size

${ }^{a}$ Prevalence rates were standardized for age and sex, prevalence rates in different age group were standardized for sex only, prevalence rates in different sex were standardized for age only. $P<0.001$ for all comparisons between subgroups

$0.007 \%$ among Swiss conscripts aged $17-38$ years [16] and $0.006 \%$ among United States male flying personnel aged $\geq 16$ years [15]. The prevalence of second-degree AV block in these studies are lower than the prevalence in our study, which may be partly due to the variation in age, race and physical fitness (the level of physical fitness may be better among conscripts and fliers). Without prompt and appropriate treatments, thirddegree AV block could be fatal. Given the relatively poor prognosis, however, very little is known about the prevalence of third-degree AV block among ostensibly healthy Chinese and it was $0.004 \%$ in our study. It was lower than the prevalence reported in the Michigan general population 0.02-0.04\% [17] and Reykjavik general population $0.04 \%$ [18]. These two studies [17, 18] including participants with obviously severe diseases which are relatively rare in health examination population. And the prevalence of third-degree AV block in our study was little higher than the prevalence among apparently healthy male flying personnel $(0.002 \%)$ [15], partly owing to the the level of physical fitness may be better among male flying personnel than health examination population.

In our study, older age and being male were significantly associated with higher risk of AV block after multivariable adjustment. These results are in agreement with previous studies $[8,19,20]$. Further, living in small city was associated with higher risk of AV block after multivariable adjustment. That can be attributed to small city (with smaller urban population) may be relevant to a combination of lower socioeconomic status, inadequate health expenditures, and insufficient medical and public health services [21]. Lower heart rate was associated with higher risk of AV block which is attributed to the pathophysiology of AV block [1]. Besides, higher BMI was also associated with higher risk of AV block in our study. That may be because obesity is strongly associated with cardiac fibrosis [22] which is the potential etiology of AV block [1].

Furthermore, hypertension and diabetes were significantly associated with higher risk of AV block. Previous studies have also found that hypertension and diabetes 
Table 3 Odds ratios (95\% Cls) for associations between risk factors and atrioventricular block

\begin{tabular}{|c|c|c|c|c|c|c|}
\hline & \multicolumn{6}{|c|}{ AV block (cases $/ \mathrm{N}=88,842 / 15,181,402$ ) } \\
\hline & Unadjusted & $P$ value & Age and sex adjusted & $P$ value & Multivariable adjusted & $P$ value \\
\hline Age, per 10 years increment & $1.73(1.72,1.74)$ & $<0.001$ & $1.73(1.72,1.74)$ & $<0.001$ & $1.66(1.64,1.67)$ & $<0.001$ \\
\hline \multicolumn{7}{|l|}{ Sex } \\
\hline Women & 1.00 & & 1.00 & & 1.00 & \\
\hline Men & $2.61(2.57,2.65)$ & $<0.001$ & $2.65(2.61,2.69)$ & $<0.001$ & $2.44(2.39,2.49)$ & $<0.001$ \\
\hline \multicolumn{7}{|l|}{ City size* } \\
\hline Small city & 1.00 & & 1.00 & & 1.00 & \\
\hline Middle city & $0.80(0.79,0.81)$ & $<0.001$ & $0.93(0.91,0.94)$ & $<0.001$ & $1.01(0.99,1.03)$ & 0.208 \\
\hline Big city & $0.54(0.53,0.55)$ & $<0.001$ & $0.68(0.67,0.69)$ & $<0.001$ & $0.78(0.76,0.80)$ & $<0.001$ \\
\hline Heart rate, per 10 bpm increment & $0.96(0.95,0.96)$ & $<0.001$ & $0.70(0.69,0.70)$ & $<0.001$ & $0.69(0.68,0.70)$ & $<0.001$ \\
\hline BMI, per $5 \mathrm{~kg} / \mathrm{m}^{2}$ increment & $1.53(1.52,1.54)$ & $<0.001$ & $1.26(1.25,1.28)$ & $<0.001$ & $1.26(1.24,1.28)$ & $<0.001$ \\
\hline Hypertension & $2.37(2.34,2.40)$ & $<0.001$ & $1.10(1.09,1.12)$ & $<0.001$ & $1.08(1.06,1.11)$ & $<0.001$ \\
\hline Diabetes & $2.58(2.53,2.63)$ & $<0.001$ & $1.23(1.21,1.26)$ & $<0.001$ & $1.20(1.17,1.23)$ & $<0.001$ \\
\hline Low HDL-C & $1.45(1.41,1.48)$ & $<0.001$ & $1.23(1.20,1.26)$ & $<0.001$ & $1.19(1.15,1.22)$ & $<0.001$ \\
\hline High LDL-C & $1.13(1.10,1.17)$ & $<0.001$ & $0.91(0.89,0.94)$ & $<0.001$ & $1.01(0.97,1.06)$ & 0.505 \\
\hline High TC & $1.12(1.10,1.15)$ & $<0.001$ & $0.88(0.86,0.90)$ & $<0.001$ & $0.88(0.85,0.91)$ & $<0.001$ \\
\hline High TG & $1.30(1.28,1.33)$ & $<0.001$ & $1.05(1.03,1.07)$ & $<0.001$ & $0.98(0.96,1.00)$ & 0.086 \\
\hline
\end{tabular}

Results are presented as odds ratios (95\% confidence intervals). Multivariable adjusted model adjusted for all co-variables listed in the table

$A V$ atrioventricular, BMI body mass index, Low HDL-C high-density lipoprotein cholesterol $<1.0 \mathrm{mmol} / \mathrm{L}$, High LDL-C low-density lipoprotein cholesterol $\geq 4.1 \mathrm{mmol} / \mathrm{L}$, High TC total cholesterol $\geq 6.2 \mathrm{mmol} / \mathrm{L}$, High TG triglyceride $\geq 2.3 \mathrm{mmol} / \mathrm{L}$

*City size was determined according to urban population size



were associated with AV block $[19,23]$. Several reasons may provide possible clues for the association between hypertension, diabetes and AV block: Hypertension and diabetes are known predispositions to myocardial infarction [24] and other cardiovascular diseases [25]. Besides, myocardial fibrosis, as a result of long-standing hypertension, may infiltrate AV conduction system, which is speculated to be a possible reason of AV block [26-28]. Additionally, metabolic derangements in diabetic cardiomyocyte could induce inflammation and fibrosis caused by cardiomyocyte injury and cell death [29]. Moreover, low HDL-C has also been observed to associate with higher risk of AV block in our study, partly because HDL-C can protect endothelial cells from inflammation and oxidative stress [30]. Furthermore, serum TC level was associated with lower risk of AV block. Only two population-based studies have investigated the association between TC and AV block and no significant correlation was found, in which the sample size is far smaller than our study $[8,19]$. However, plenty of researches have reported the inverse association between TC and atrial fibrillation [31-33]. Cholesterol is a prominent component of membranes and are known to affect properties of cell electrophysiology, which may be implicated in the etiology of cardiac arrhythmias [34, 35]. Further, cholesterol may have a beneficial effect on the immune system and could protect against infections [36]. Nevertheless, the mechanisms underlying the inverse association between TC and AV block have not been defined. Further researches are warranted. 


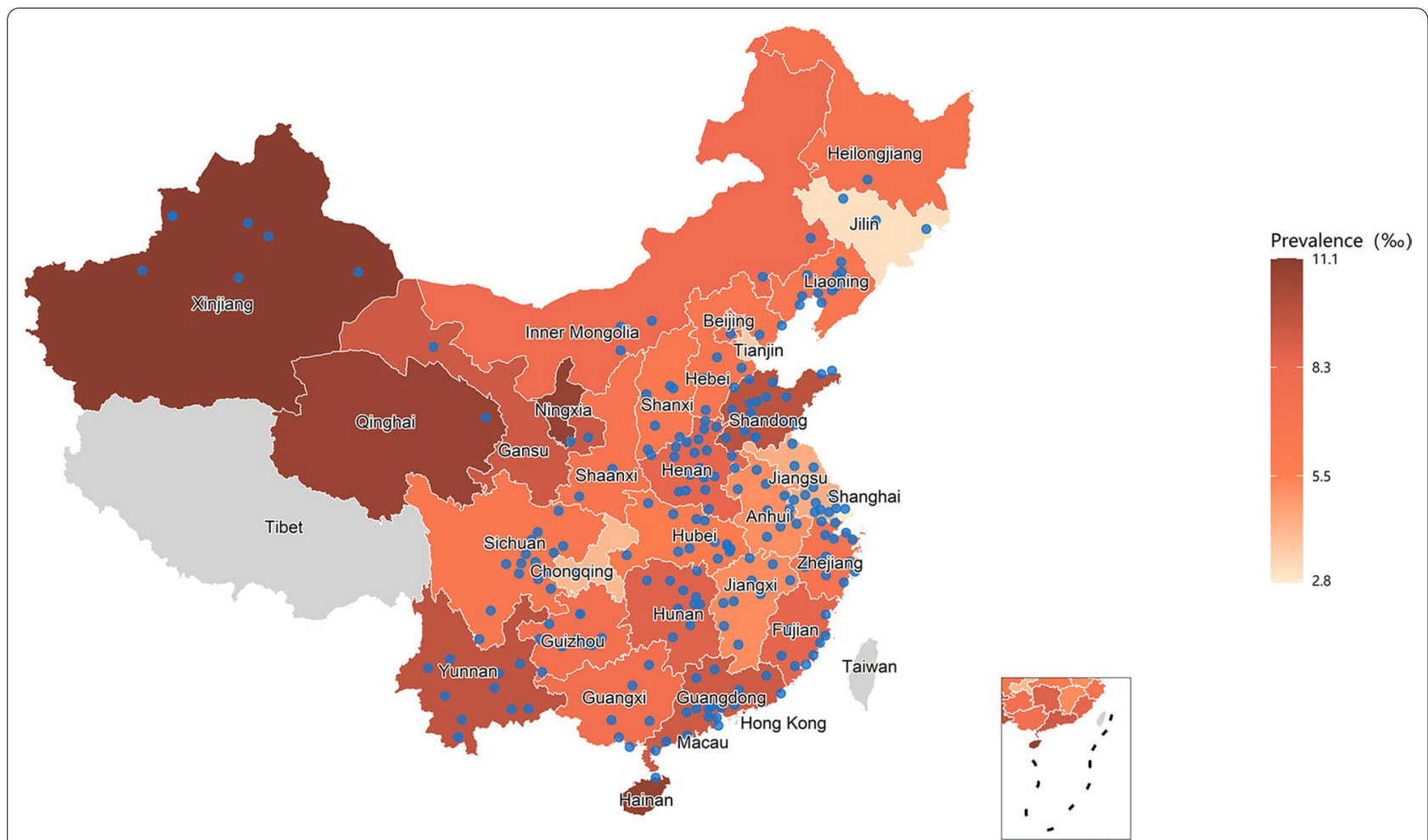

Fig. 2 Age- and sex-standardized prevalence of atrioventricular block among Chinese health examination adults in 2018. Data from all province of mainland China were available except Tibet. Blue points represent the locations of 224 cities included in this study

\section{Strengths and limitations}

To our knowledge, this is the first nationwide epidemiological study on the prevalence of first-, second- and third-degree AV block and related risk factors undertaken in China and this is also the first study assessed the prevalence of AV block not only among elderly but also among younger Chinese adults. Moreover, this study based on 15,181,402 Chinese adults covering almost all geographic areas in China, which are various in socioeconomic and geographic features, providing important information for allocating healthcare resources appropriately. Nevertheless, several limitations should be mentioned. First, this was a research based on physical examination population, most of them were ostensibly healthy and without severe clinical symptoms, the generalizability of the results to general population should be made with caution. Secondly, due to our study results are limited by cross-sectional design, further researches are warranted to verify our conclusion on the potential risk factors. Thirdly, information on education level, diet and lifestyle were not available in our studies, which restricted our ability to explore the underlying related risk factors.

\section{Conclusions}

First-degree AV block are most frequently found, second- and third-degree are relatively rare among ostensibly healthy participants. The prevalence of AV block increased significantly with age. Managing metabolic risk factors may be beneficial for preventing AV block. Despite the limitation mentioned before, this study provides unique and valuable evidence for the future population prevention strategies on AV block.

\section{Abbreviations \\ AV block: Atrioventricular block; ECG: Electrocardiogram; BMI: Body mass index; FBG: Fasting blood glucose; HDL-C: High-density lipoprotein choles- terol; LDL-C: Low-density lipoprotein cholesterol; TC: Total cholesterol; TG: Triglyceride; Cl: Confidence interval.}

\section{Supplementary Information}

The online version contains supplementary material available at https://doi. org/10.1186/s12872-021-02105-3.

Additional file 1. Prevalence of atrioventricular block by age groups and by provinces. 


\section{Acknowledgements}

We thank all participants and staff members involved in this study and appreciate the contributions made by Dr. Cheng Jin.

\section{Authors' contributions}

YN, LL and RS contributed to the study design. RS drafted the manuscript. YM and RS analyzed the data. SL and RS consulted literatures. JW, XF, JL, BW, SL reviewed and revised the manuscript. All authors read and approved the final manuscript.

\section{Funding}

This work was supported by the National Natural Science Foundation of China (91846303) and the National Key R\&D Program of China (2020YFC2003400). The funders had no role in the study design, data collection, data analysis and interpretation, writing of the manuscript, or the decision to submit the article for publication.

\section{Availability of data and materials}

The datasets used and/or analysed during the current study are available from the corresponding author on reasonable request.

\section{Declarations}

\section{Ethics approval and consent to participate}

The study was approved by the Peking University Institutional Review Board with a waiver of informed consent (IRB00001052-19077). All methods were carried out in accordance with relevant guidelines and regulations. Data on individual identification were removed and only anonymous information was kept during the study process.

\section{Consent for publication}

Not applicable.

\section{Competing interests}

The authors declare that they have no competing interests.

\section{Author details}

${ }^{1}$ Department of Epidemiology and Biostatistics, School of Public Health, Peking University Health Science Center, 38 Xueyuan Road, Beijing 100191 , China. ${ }^{2}$ Peking University Health Science Center Meinian Public Health Institute, 35 North Huayuan Road, Beijing 100191, China. ${ }^{3}$ Peking University Center for Public Health and Epidemic Preparedness \& Response, Beijing, China. ${ }^{4}$ Meinian Institute of Health, Beijing, China. ${ }^{5}$ Department of Anesthesiology, The Fourth Affiliated Hospital of Harbin Medical University, Harbin, China. ${ }^{6}$ Department of Cardiology, Fuwai Hospital, National Center for Cardiovascular Diseases, Chinese Academy of Medical Sciences and Peking Union Medical College, Beijing, China.

Received: 11 March 2021 Accepted: 7 June 2021 Published online: 11 June 2021

\section{References}

1. Kashou AH, Goyal A, Nguyen T, Chhabra L. Atrioventricular block. StatPearls. Treasure Island: StatPearls Publishing; 2020.

2. Epstein AE, DiMarco JP, Ellenbogen KA, Estes NA 3rd, Freedman RA, Gettes LS, et al. ACC/AHA/HRS 2008 Guidelines for Device-Based Therapy of Cardiac Rhythm Abnormalities: a report of the American College of Cardiology/American Heart Association Task Force on Practice Guidelines (Writing Committee to Revise the ACC/AHA/NASPE 2002 Guideline Update for Implantation of Cardiac Pacemakers and Antiarrhythmia Devices) developed in collaboration with the American Association for Thoracic Surgery and Society of Thoracic Surgeons. J Am Coll Cardiol. 2008:51:e1-62.

3. Cheng S, Keyes MJ, Larson MG, McCabe EL, Newton-Cheh C, Levy D, et al. Long-term outcomes in individuals with prolonged PR interval or firstdegree atrioventricular block. JAMA. 2009;301:2571-7.

4. Crisel RK, Farzaneh-Far R, Na B, Whooley MA. First-degree atrioventricular block is associated with heart failure and death in persons with stable coronary artery disease: data from the Heart and Soul Study. Eur Heart J. 2011;32:1875-80.

5. Aro AL, Anttonen O, Kerola T, Junttila MJ, Tikkanen JT, Rissanen HA, et al Prognostic significance of prolonged PR interval in the general population. Eur Heart J. 2014;35:123-9.

6. Knabben V, Chhabra L, Slane M. Third-degree atrioventricular block. StatPearls. Treasure Island: StatPearls Publishing; 2020.

7. Sutton R. Mobitz type 1 second degree atrioventricular block: the value of permanent pacing in the older patient. Heart. 2013;99:291-2.

8. Du Z, Xing L, Lin M, Tian Y, Jing L, Yan H, et al. Prevalence of first-degree atrioventricular block and the associated risk factors: a cross-sectional study in rural Northeast China. BMC Cardiovasc Disord. 2019;19:214.

9. Qi W, Liu SH, Jin HR. Applicability of the new standard of city-size classification in China. Prog Geogr. 2016:35:47-56.

10. Joint Committee for Guideline Revision. 2018 Chinese Guidelines for Prevention and Treatment of Hypertension-a report of the Revision Committee of Chinese Guidelines for Prevention and Treatment of Hypertension. J Geriatr Cardiol. 2019;16:182-241.

11. Chang CQ, Chen JW, Chen W, Chen Y, Dou P, Feng Y, et al. Writing committee of expert consensus on overweight/obesity medical nutrition therapy in China. Expert consensus on overweight/obesity medical nutrition therapy in China. Chin J Diabetes Mellitus 2016:8:525-40.

12. Alberti KG, Zimmet PZ. Definition, diagnosis and classification of diabetes mellitus and its complications. Part 1: diagnosis and classification of diabetes mellitus provisional report of a WHO consultation. Diabet Med. 1998;15:539-53.

13. Zhu JR, Gao RL, Zhao SP, Lu GP, Zhao D, Li JJ, et al. Joint Committee for Developing Chinese guidelines on Prevention and Treatment of Dyslipidemia in Adults. 2016 Chinese Guidelines for prevention and treatment of dyslipidemia in adults. Chin Circ J 2016;31:937-53.

14. Hisamatsu T, Miura K, Fujiyoshi A, Okamura T, Ohkubo T, Nagasawa SY, et al. Long-term outcomes associated with prolonged PR interval in the general Japanese population. Int J Cardiol. 2015;184:291-3.

15. Hiss RG, Lamb LE. Electrocardiographic findings in 122,043 individuals. Circulation. 1962;25:947-61.

16. Kobza R, Cuculi F, Abacherli R, Toggweiler S, Suter Y, Frey F, et al. Twelvelead electrocardiography in the young: physiologic and pathologic abnormalities. Heart Rhythm. 2012;9:2018-22.

17. Ostrander LD Jr, Brandt RL, Kjelsberg MO, Epstein FH. Electrocardiographic findings among the adult population of a total Natural Community, Tecumseh, Michigan. Circulation. 1965;31:888-98.

18. Kojic EM, Hardarson T, Sigfusson N, Sigvaldason $\mathrm{H}$. The prevalence and prognosis of third-degree atrioventricular conduction block: the Reykjavik study. J Intern Med. 1999;246:81-6.

19. Kerola T, Eranti A, Aro AL, Haukilahti MA, Holkeri A, Junttila MJ, et al. Risk factors associated with atrioventricular block. JAMA Netw Open. 2019;2:e194176.

20. Tadros R, Ton AT, Fiset C, Nattel S. Sex differences in cardiac electrophysiology and clinical arrhythmias: epidemiology, therapeutics, and mechanisms. Can J Cardiol. 2014;30:783-92.

21. Murray CJ, Lopez AD. Measuring the global burden of disease. N Engl J Med. 2013;369:448-57.

22. Cavalera M, Wang J, Frangogiannis NG. Obesity, metabolic dysfunction, and cardiac fibrosis: pathophysiological pathways, molecular mechanisms, and therapeutic opportunities. Transl Res. 2014;164:323-35.

23. Meine TJ, Al-Khatib SM, Alexander JH, Granger CB, White HD, Kilaru R, et al. Incidence, predictors, and outcomes of high-degree atrioventricular block complicating acute myocardial infarction treated with thrombolytic therapy. Am Heart J. 2005;149:670-4.

24. Yusuf S, Hawken S, Ounpuu S, Dans T, Avezum A, Lanas F, et al. Effect of potentially modifiable risk factors associated with myocardial infarction in 52 countries (the INTERHEART study): case-control study. Lancet. 2004;364:937-52.

25. Yusuf S, Reddy S, Ounpuu S, Anand S. Global burden of cardiovascular diseases: part I: general considerations, the epidemiologic transition, risk factors, and impact of urbanization. Circulation. 2001;104:2746-53.

26. Lionakis N, Moyssakis I, Gialafos E, Dalianis N, Votteas V. Aortic dissection and third-degree atrioventricular block in a patient with a hypertensive crisis. J Clin Hypertens (Greenwich). 2008;10:69-72.

27. Diez J, Lopez B, Gonzalez A, Querejeta R. Clinical aspects of hypertensive myocardial fibrosis. Curr Opin Cardiol. 2001;16:328-35. 
28. Querejeta R, Lopez B, Gonzalez A, Sanchez E, Larman M, Martinez Ubago $\mathrm{J}$, et al. Increased collagen type I synthesis in patients with heart failure of hypertensive origin: relation to myocardial fibrosis. Circulation. 2004;110:1263-8.

29. Falcao-Pires I, Leite-Moreira AF. Diabetic cardiomyopathy: understanding the molecular and cellular basis to progress in diagnosis and treatment. Heart Fail Rev. 2012:17:325-44.

30. Ganjali S, Gotto AM Jr, Ruscica M, Atkin SL, Butler AE, Banach M, et al. Monocyte-to-HDL-cholesterol ratio as a prognostic marker in cardiovascular diseases. J Cell Physiol. 2018;233:9237-46.

31. Magnussen C, Niiranen TJ, Ojeda FM, Gianfagna F, Blankenberg S, Njolstad I, et al. Sex differences and similarities in atrial fibrillation epidemiology, risk factors, and mortality in community cohorts: results From the BiomarCaRE Consortium (Biomarker for Cardiovascular Risk Assessment in Europe). Circulation. 2017;136:1588-97.

32. Guan B, Li X, Xue W, Tse G, Waleed KB, Liu Y, et al. Blood lipid profiles and risk of atrial fibrillation: a systematic review and meta-analysis of cohort studies. J Clin Lipidol. 2020;14:133-42.e3.
33. Psaty BM, Manolio TA, Kuller LH, Kronmal RA, Cushman M, Fried LP, et al. Incidence of and risk factors for atrial fibrillation in older adults. Circulation. 1997;96:2455-61.

34. Bastiaanse EM, Hold KM, Van der Laarse A. The effect of membrane cholesterol content on ion transport processes in plasma membranes. Cardiovasc Res. 1997;33:272-83.

35. Lijnen P. The effect of membrane cholesterol content on ion transport processes in plasma membranes. Cardiovasc Res. 1997;35:384-6.

36. Ravnskov U. High cholesterol may protect against infections and atherosclerosis. QJM. 2003;96:927-34.

\section{Publisher's Note}

Springer Nature remains neutral with regard to jurisdictional claims in published maps and institutional affiliations.
Ready to submit your research? Choose BMC and benefit from:

- fast, convenient online submission

- thorough peer review by experienced researchers in your field

- rapid publication on acceptance

- support for research data, including large and complex data types

- gold Open Access which fosters wider collaboration and increased citations

- maximum visibility for your research: over 100M website views per year

At BMC, research is always in progress.

Learn more biomedcentral.com/submissions 